\title{
PEST CONTROL IN GREEN GRAM SEEDS (Vigna radiata) BY USING PLANT EXTRACTS
}

\author{
Poornasundari B. ${ }^{1}$ \\ (Post Graduate Student) \\ Thilagavathy Daniel ${ }^{2}$ \\ ${ }^{1}$ Gandhigram Rural Institute-Deemed University, Gandhigram-624302, Tamil Nadu, India \\ ${ }^{2}$ Department of Biology, Gandhigram Rural Institute-Deemed University, Gandhigram - 624302, \\ Tamil Nadu, India \\ E-mail address: Sundari.balusakthi @gmail.com
}

Keywords: Callosobruchus chinensis; Citrus lemon; Piper nigram; Toxicity; Vigna radiate

\begin{abstract}
A experiment was conducted to investigate the efficacy of different plant derivatives against the development of the green gram pest Callosobruchus chinensis (L). fed on green gram seeds Vigna radiate for one month period. The leaf extracts of lemon (Citrus lemon), mint (Mentha arvensis) and black pepper seed (Piper nigram) powders were evaluated for their growth, adult mortality and oviposition inhibition of Callosobruhus chinensis. The results revealed that the extracts of all the three plant products caused a considerable reduction in the number of bruchids. Among the treatments Piper nigram were found to be effective in destroying the pest.
\end{abstract}

\section{INTRODUCTION:}

Green gram is an important pulse crop in India. It is a plant species of legume family. The green gram is also known as golden gram, mung bean and moong bean and it is mainly cultivated in the Indian subcontinent. Green gram contains a lot of proteins and it is rich in vitamin B, C, magnesium and minerals like calcium and potassium, which is essential for enhancing the strength of bones and teeth. The stored pulses are affected by pests which cause economic loss to people. The stored green gram is affected by bruchids. The pulse beetle, Callosobruchus chinensis is the most wide spread and destructive insect pest of economically important leguminous green gram. The insect spends its entire immature stage in individual legume seeds, where it causes weight loss, decrease in germination potential and diminishes the market as well as nutritional value of the commodity. Due to short life cycle and high degree of reproductive capacity, losses caused by this beetle to the pulses have been estimated to the tune of $30-40$ percent in storage. In the stored products insect pests not only feed on the food grain but also oviposition as well as cause organic changes, bad odours, fermentation and acidification of the food grains which reduces the nutritional value. The pest control of C.chinensis is very important to protect the loss of nutritive and economic value of green gram. Synthetic insecticides, viz. organophosphates and fumigants are mainly used as effective means to control this insect population for the protection of stored food from insect infestation. These chemicals loose their effectiveness gradually due to development of resistance in C. chinensis. The use of synthetic insecticide is very injurious and repeated uses have created several problems such as insect resistance and toxic residues in food grains. Therefore, alternative methods such as the use of ash, edible oils and plant products that could be easily used by farmers need to be considered. They are environmentally safe, less hazardous, less expensive and readily available. Some are less toxic to mammals, may be more selective in action, and may retard the development of resistance. When the plant products are mixed with stored-grains, leaf, bark, seed powder, or oil extracts of plants reduce oviposition rate and suppress adult emergence of bruchids, and also reduced seed damage rate. This paper describes the bio-efficacy of some edible oils and plant products against pulse beetle, Callosobruchus chinensis which is infesting stored green gram, with brief reviews. 


\section{MATERIALS AND METHODS:}

These pulse beetles were cultured in fresh seeds of green gram kept in plastic containers to obtain sufficient number of test insects for the experiment by using adult members of Callosobruchus chinensis. The newly emerged beetles were collected from the rearing jar and used for the bioassay study. The plant materials of lemon and mint were collected from local environment. Black pepper seeds were procured from local market. All the plant materials were shade dried for a period of 2-3 weeks. The dried leaves were manually ground into powder with the help of a blender. The resulting powders were kept in polythene bags for further use. Fresh green gram seeds were used for this experimental study. The lemon (Citrus lemon) and Mint (Mentha arvensis) leaf powders at different doses such as 1,2,3 and $4 \mathrm{~g}$ were mixed with $40 \mathrm{~g}$ of green gram seeds, separately. Black pepper (Piper nigrum) powder at doses 0.5, 1.0, 1.5 and 2.0g were taken and mixed with $40 \mathrm{~g}$ of green gram seeds. All the experiments were carried out in triplicate. The plastic containers were shaken horizontally for 5 minutes to ensure a uniform coating of the test plant powders and black pepper powder on these seeds. Untreated seeds served as control. After treatment with the plant product, 3 pairs of newly emerged beetles were released in the jar containing $40 \mathrm{~g}$ of green gram seeds After $24 \mathrm{hrs}$ interval the green gram seeds treated with different concentrations of plant powders and volatile oils were tested for the protective effect on them, also the physical parameters (A number of bore holes, percent weight loss and protection of seeds), biological parameters (number of eggs laid, number of adult emergences, percent adult mortality) and growth index were observed.

\section{RESULT AND DISCUSSION}

The result were observed in the pest Callosobruhus chinensis had mortality on treating with the plant products were as there is no mortality is observed in control. $100 \%$ mortality rate is observed in the pest treated with lemon leaf powder at two days interval on $18^{\text {th }}$ day. The $100 \%$ mortality of Callosobruchus chinensis is showed in mint leaf powder at daily observation on $16^{\text {th }}$ day of the study. Among those three plant products the highest mortality rate is observed in green gram seeds treated with black pepper powder in higher concentration i.e $2 \mathrm{~g}$ in $8^{\text {th }}$ day observation. The hole formation is caused by Callosobruchus chinensis is observed in the green grams treated with lemon leaf powder and control and there is no hole formation is observed in Mentha arvensis and Piper nigram treated green gram seeds. Weight loss is high in the green gram seeds treated with lemon and no loss of weight in the fresh seeds treated with the plant product of mint and pepper. The seed germination is observed in before and after the treatment, no difference in the treatment. hole formation. Weight loss, loss of seed germination and no mortality were observed in control.

\section{CONCLUSION}

From the present study it was inferred that the plant products play a vital role in controlling the infestation of Callosobruchus chinensis in stored green gram seeds. Among the treatments piper nigram were found to be effective in controlling the pest. In a separate set of experiments on the efficacy of plant product against the bruchids it was clear that powder of Piper nigram, Citrus limon, Mentha arvensis, provide promising and were quite effective in providing protection to green gram seeds in one month study. The farmer could, therefore utilize these products for safe seed storage as they were not only effective against callosobruchus chinensis infestation but also convenient to use and easily available in the local market place. 


\section{References}

[1] Babu,T.R., Reddy,V.S. and Hussaini S.H., Effect of edible and non-edible oils on the development of the pulse beetle (Callosobruchus chinensis L.) and on viability and yield of mungbean (Vigna radiata [L]:29, (1978) 215-220.

[2] Doharey, K.L. and Singh. R.P., Evaluation of neem (Azadirachta indica, A.juss) seed kernel extract against chafer beetles, Indian Journal of Entomology. (1989) 217-219.

[3] Patil AD and Tandale MB. (1999). Efficacy of plant products against pulse beetle. Thesis Abstract. (1999) 302-303.

[4] Gautam, P., Vaidya, D., Evaluation of beetle, Callosobruchus analis [F]. infesting green gram. Pest Management and economic Zoology. (2000) 145-150.

[5] Rathore, Y.S., Sharma, V., Management of bruchid infestation in pulse. (2002) 111-124.

[6] Khalequzzaman,M., Mahdi.S.H.A and Osman goni, S.H.M., Efficacy of edible oils in the control of pulse beetle Callosobruchus chinensis L. In stored pigeon pea. 26, (2007) 89-92,

[7] Rathore, Y.S., Sharma, V., Management of bruchid infestation in pulse. (2002) 111-124,

[8] Singh, P. K., Effect of some oils against pulse beetle, Callosobruchus chinensis (Linn.) infesting pigeon pea. Indian Journal of Entomology. (2003) 55-58.

[9] Jat, N.R., Rana, B.S., and Jat. S.K., Estimation of losses due to pulse beetle in chickpea. An International Quaterly Journal of Life Sciences. (2012) 861-863. 